\title{
Health reform and the Medical Journal of Australia
}

\author{
Elizabeth C Kalucy and Eleanor M Jackson Bowers
}

T hree major health reform initiatives - the National Health and Hospitals Reform Commission (NHHRC), ${ }^{1}$ National Primary Health Care Strategy (NPHCS) working group ${ }^{2}$ and Preventative Health Taskforce $(\mathrm{PHT})^{3}$ — released their final reports during 2009. Their processes were remarkably open. Consistent with the Australian Government's commitment to evidence-informed policy, ${ }^{4,5}$ each working group placed discussion papers, commissioned papers, submissions and reports on websites in the public domain. ${ }^{6-9}$ This gave us a rare opportunity to identify the evidence and publications that are used by such working groups to develop their health reform options. The inclusion of citations in final reports allowed analysis of the forms of evidence that supported their decisions

\section{What did we do?}

As part of a broader study of the contribution of primary health care research to the health reform initiatives, ${ }^{10}$ we identified which journals were most frequently cited in the health reform documents. We extracted and coded all references cited in the publicly available discussion documents $(n=4)$, submissions $(n=1264)$, commissioned papers $(n=25)$, an interim report, and final reports $(n=3)$ from the websites of the three reform initiatives. ${ }^{6-8}$ As the variety of referencing styles limited the accuracy of the dataset, we undertook more intensive data cleaning and coding of the journal subset to identify the most commonly cited journals. We used Microsoft Excel to organise and code data, and SPSS Version 17.0 for Windows (SPSS Inc, Chicago, Ill, USA) to

1 Type of documents cited in discussion documents, commissioned papers and submissions $(n=8143)$

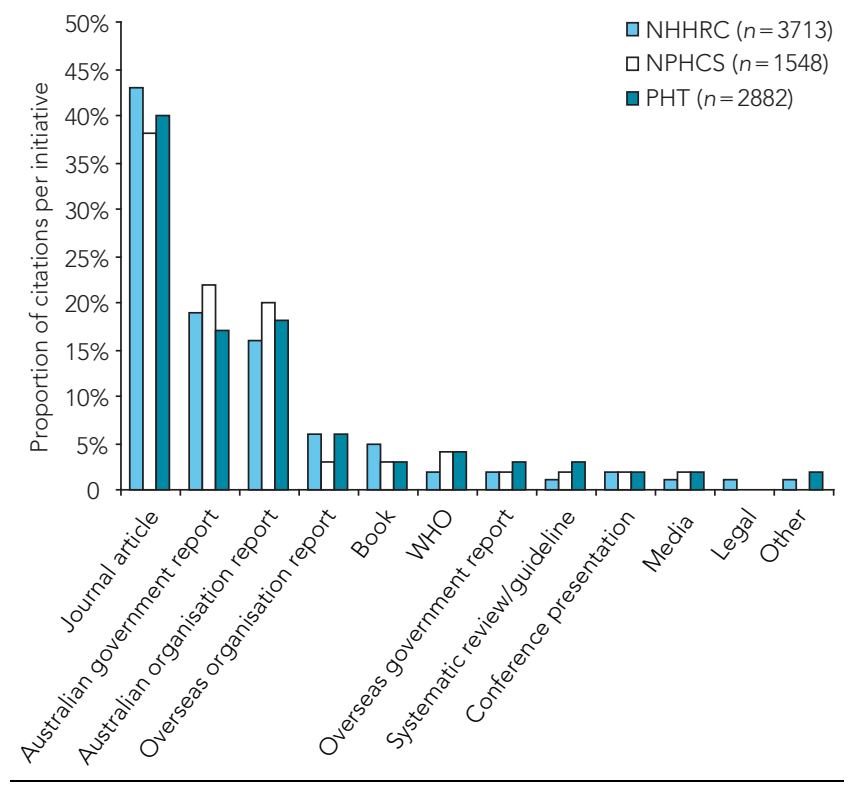

NHHRC $=$ National Health and Hospitals Reform Commission.

$\mathrm{NPHCS}=$ National Primary Health Care Strategy. $\mathrm{PHT}=$ Preventative Health Taskforce. $\mathrm{WHO}=$ World Health Organization.

\section{ABSTRACT}

- In 2008, the Australian Government established three major health reform initiatives — the National Health and Hospitals Reform Commission, the first National Primary Health Care Strategy working group, and the Preventative Health Taskforce.

- We examined which journals were most frequently cited in the publicly available discussion papers, commissioned papers, submissions and final reports of these initiatives.

- Journal articles were cited most in discussion papers, commissioned papers and submissions, followed by reports and other publications from Australian organisations and governments.

- The Medical Journal of Australia was the most cited journal, with 392 references to its articles (11.8\% of all journal articles cited) in discussion papers, commissioned papers, submissions and an interim report, and 58 references to its articles (13.7\% of total journal articles) in the three final reports.

- Our findings demonstrate the importance of credible, local, accessible, peer-reviewed evidence in reforming the national health system, including hospitals, primary health care and preventive health care.

MJA 2010; 193: 78-79

obtain frequencies. Ethics approval was not required, as all data were in the public domain.

\section{What did we find?}

Discussion documents, commissioned papers, submissions and the interim NHHRC report ${ }^{11}$ contained 8143 references, with almost half $(46 \%$; 3713) in documents associated with the NHHRC, 35\% (2882) with the PHT and 19\% (1548) with the NPHCS. Journal articles were cited most frequently, followed by reports and other publications by government organisations such as the Australian Institute of Health and Welfare and Australian Bureau of Statistics, and documents from Australian university research groups, non-government organisations and private companies. The pattern varied little among the three initiatives (Box 1).

Overall, the Medical Journal of Australia (MJA) was the most frequently cited journal, with 392 references to its articles (11.8\% of the total 3321 journal articles cited). The second most cited journal was the BMJ, with 150 citations (4.5\%), followed by Tobacco Control, with 131 citations (3.9\%), which was cited almost exclusively in documents relating to the PHT (Box 2). A total of 817 journals were cited, with the top 10 providing $32 \%$ of citations.

Submissions were cited in the final reports of the NHHRC and NPHCS, but not the PHT. Australian government reports dominated the types of document cited in the final reports of the NHHRC and NPHCS, while the PHT final report cited more journal articles than other types of publication. 
2 Most cited journals in discussion documents, commissioned papers, submissions and the interim NHHRC report

\section{More than 100 citations \\ Medical Journal of Australia (392), BMJ (150), Tobacco Control (131) \\ 50-100 citations ${ }^{* \dagger}$ \\ American Journal of Public Health, JAMA, The Lancet, New England Journal of Medicine \\ Less than 50 citations ${ }^{*}$ \\ Addiction, American Journal of Preventive Medicine, Annals of Internal Medicine, Australian Family Physician, Australian Health Review, Australian Journal of Primary Health, Australian Journal of Rural Health, Australian and New Zealand Health Policy, Australian and New Zealand Journal of Psychiatry, Australian and New Zealand Journal of Public Health, British Journal of Psychiatry, Drug and Alcohol Review, Health Affairs, Health Policy, Health Promotion International, Health Promotion Journal of Australia, Internal Medicine Journal, Journal of Epidemiology and Community Health, Journal of Intellectual Disability Research, Journal of Telemedicine and Telecare, Milbank Quarterly, Pediatrics, Quality and Safety in Health Care, Social Science and Medicine}

$\mathrm{NHHRC}=$ National Health and Hospitals Reform Commission * Journals are listed alphabetically. †Range, 57 to 75 . ¥Range, 15 to 47

The MJA was the most frequently cited journal in the NHHRC and NPHCS final reports, but was overtaken by Tobacco Control in the PHT final report. Overall, the MJA was the most frequently cited journal in all three final reports, with 58 references to its articles (13.7\% of the 422 journal articles cited in the final reports). Citations in the final reports were spread over more than 160 journals, the top 10 journals providing $44 \%$ of citations

\section{What does it mean?}

Of the many sources of evidence used to support arguments for reform, peer-reviewed journals were cited most frequently. The "grey" literature, such as government reports from reputable independent organisations, including the Australian Institute of Health and Welfare and Australian Bureau of Statistics, also played a prominent role. The dominance of MJA citations in consultation documents and final reports demonstrates that its published content was accessible, credible, valued and relevant to the broad health reform agenda of these diverse initiatives.

Limitations to our study included the wide range and variable accuracy of referencing styles, which made it difficult to compile the data accurately. Our results should be seen as indicative only, and we therefore avoided ranking journals, apart from the first three, where the margin for error would not have made a difference. Our study examined just the visible tip of the evidence iceberg for the three working groups. The final reports mark the completion of the policy-development stage and the start of the decision-making stage, in which research competes with other forms of evidence and experience.

\section{Acknowledgements}

The Primary Health Care Research and Information Service is a component of the federal government's Primary Health Care Research, Evaluation and Development Strategy.

\section{Competing interests}

None identified.

\section{Author details}

Elizabeth C Kalucy, BSc, MSc, Dip Ed, Director

Eleanor M Jackson Bowers, BA(Soc Sci), MNurs, GradDiplnfoStud, Research Associate

Primary Health Care Research and Information Service, Department of General Practice, Flinders University, Adelaide, SA.

Correspondence: libby.kalucy@flinders.edu.au

\section{References}

1 National Health and Hospitals Reform Commission. A healthier future for all Australians: final report June 2009. Canberra: Commonwealth of Australia, 2009. http://www.yourhealth.gov.au/internet/yourhealth/publishing.nsf/Content/nhhrc-report-toc (accessed May 2010).

2 Department of Health and Ageing. Building a 21st century primary health care system: a draft of Australia's first National Primary Health Care Strategy. Canberra: Commonwealth of Australia, 2009. http://www.yourhealth.gov.au/internet/yourhealth/publishing.nsf/Content/nphc-draftreport-toc (accessed May 2010).

3 National Preventative Health Taskforce. Australia: the healthiest country by 2020 - National Preventative Health Strategy - the roadmap for action. Canberra: Commonwealth of Australia, 2009. http://www.yourhealth.gov.au/internet/yourhealth/publishing.nsf/Content/nphs-reportroadmap (accessed May 2010).

4 National Health and Hospitals Reform Commission. Principles for Australia's health system. Canberra: Commonwealth of Australia, 2008. http:// www.health.gov.au/internet/nhhrc/publishing.nsf/Content/principles-lp (accessed May 2010).

5 Banks G. Challenges of evidence-based policy-making. Productivity Commission and Australian Public Service Commission report. Canberra: Commonwealth of Australia, 2009. http://www.apsc.gov.au/ publications09/evidencebasedpolicy.pdf (accessed May 2010).

6 National Health and Hospitals Reform Commission. A healthier future for all Australians: final report June 2009. Appendix D: discussion papers; Appendix E: submissions in response to the NHHRC Interim report. Canberra: Commonwealth of Australia, 2009. http://www.yourhealth.gov.au/internet/yourhealth/publishing.nsf/Content/nhhrc-reporttoc (accessed May 2010).

7 Department of Health and Ageing. Primary Health Strategy submissions. http://www.health.gov.au/internet/main/publishing.nsf/Content/primaryhealthstrategy-submissions (accessed May 2010).

8 Preventative Health Taskforce. Submissions. http://www.preventativehealth.org.au/internet/preventativehealth/publishing.nsf/Content/submissions-1lp (accessed May 2010).

9 Department of Health and Ageing. yourHealth. http://www.yourhealth.gov.au (accessed May 2010).

10 Kalucy L, Jackson Bowers E. Primary Health Care Research Contribution Project: the contribution of primary health care research to the 2008-9 health reform process in Australia. Adelaide: Flinders University, 2009. http://www.phcris.org.au/phplib/filedownload.php?file=/elib/lib/ downloaded_files/publications/pdfs/phcris_pub_8325.pdf (accessed May 2010).

11 National Health and Hospitals Reform Commission. A healthier future for all Australians: interim report December 2008. Canberra: Commonwealth of Australia, 2009. http://www.health.gov.au/internet/nhhrc/publishing.nsf/Content/interim-report-december-2008 (accessed May 2010). 